\title{
Tiszta érdekkonfliktusok során jelentkező viselkedési szándékot befolyásoló tényezők - a társas értékorientáción túl
}

Sipos Sándor

Csízik Tímea

Hunya Pál

\author{
Debreceni Egyetem, Pszichológiai Intézet \\ Szociál- és Munkapszichológiai Tanszék \\ Teva Gyógyszergyár Zrt. \\ E-mail: sipos.sandor.andras@gmail.com
}

Debreceni Egyetem, Pszichológiai Intézet Szociál- és Munkapszichológiai Tanszék E-mail: csizikt@puma.unideb.hu

Debreceni Egyetem, Pszichológiai Intézet Szociál- és Munkapszichológiai Tanszék E-mail: hunyapal@hotmail.com

\begin{abstract}
ABSZTRAKT
A társas értékorientáció Messick és McClintock (1968) által meghatározott fogalma a kölcsönös függöségi helyzetek vizsgálatával foglalkozó kutatások többségének alappillérét képezi. Messick és McClintock (1968) elmélete alapján az emberek tipizálhatók aszerint, hogy egy kölcsönös függőségi helyzetben milyen végeredmény elérését preferálják. Vizsgálatok sora (pl. Kelley, Stahelski, 1970; Kuhlman, Marshello, 1975; Maki, McClintock, 1983; Roch, Samuelson, 1997; Van Lange, Visser, 1999; Van Lange et al., 2007a) talált kapcsolatot a társas értékorientáció és a kölcsönös függőségi helyzetekben mutatott viselkedési preferencia között, elsősorban kísérleti játszmák módszerével vizsgálva mind a társas értékorientációt, mind a viselkedést vagy viselkedési szándékot. Más kutatások (pl. Bixenstine, Wilson, 1969; Oskamp, 1971; Rapoport, 1976; Kelley, Thibault, 1978, in: Kelley et al., 2003; Axelrod, 1984; Pillutla, Chen, 1999) arra irányultak, hogy különbözö, a szituációra jellemző változók hatását vizsgálják a kölcsönös függőségi helyzetekben mutatott viselkedésre. Kutatásunkban két ilyen szituációra jellemző változó: a felek érdekeinek méltányossága, illetve a partner stratégiája; valamint az egyénre jellemző társas értékorientáció viselkedési szándékra való befolyását vizsgáltuk. Azt feltételeztük, hogy az emberek versengőbb viselkedési szándékot alakítanak ki akkor, ha a saját érdekeiket méltányosabbnak ítélik meg, mint a partnerét, és akkor, ha a partner versengő stratégiát folytat, valamint hogy helyzettől függetlenül a versengő vagy individualista (proself) társas értékorientációval rendelkező egyének versengőbb viselkedési szándékot alakítanak ki, mint a proszociálisok. Vizsgálati konstrukciónk a kísérleti játszmák megszokott módszerétől eltérő, életszerü helyzetleírásokat tartalmazott, melyek elolvasása után kellett a vizsgálati személyeknek megfogalmazniuk viselkedési intencióikat. Hipotéziseink közül a szituáció jellemzőinek (méltányosság és partner stratégiája) hatására vonatkozók igazolást nyertek, de nem sikerült kapcsolatot kimutatnunk a társas értékorientáció és a viselkedési szándék között. Igazoltuk ugyanakkor, hogy vizsgálati mintánk a méltányossági viszonyok és a partner stratégiájának észleletében, valamint a viselkedési szándék kialakításában szignifikánsan különböző alcsoportokra bontható. Sikerült tehát individuális különbözőségeket találnunk az emberek észlelési stílusában és viselkedési szándékuk kialakításának stratégiájában, de ezek az egyéni eltérések nem kapcsolhatók össze az általunk felmért társas értékorientációval.
\end{abstract}

Életünk mindennapjait érdekkonfliktusok egymásba fonódó rendszereiben töltjük. Bár a konfliktus szónak hajlamosak vagyunk negatív jelentést tulajdonítani, és úgy gondolni rá, mint egy ritkán előforduló, de annál kellemetlenebb helyzetre, mellyel jobb minél kevesebbszer találkozni és minél gyorsabban túl lenni rajta, valójában társas érintkezéseink jókora része érdekkonfliktusként értelmezhető. Ezek a konfliktusok gyakran kis jelentőségüek számunkra, és sokszor egyáltalán nem is tudatosodik bennünk érdekellentétes sajátosságuk, mégis igazak rájuk az érdekkonfliktusok alapjellemzői. Ezeket a szituációkat a szociálpszichológia hagyományai szerint kölcsönös függöségi helyzetekként definiálhatjuk. Kölcsönös függőségi helyzetnek azokat a társas szituációkat nevezzük, amelyekben az érintett felek által preferált kimenetelek egyaránt függnek mind az egyik, mind a másik fél 
cselekedeteitől (Kelley, Thibault, 1978, in: Kelley et al., 2003). Attól függően, hogy a felek érdekei milyen mértékben ütköznek egymással, a kölcsönös függőségi helyzetek három típusát különíthetjük el. Amennyiben nincs érdekütközés a felek között, koordinációs helyzetröl beszélünk - ez esetben a résztvevők közösen keresik meg a helyzet mindkettejük számára legjobb megoldását. Amennyiben az érdekütközés teljes, azaz az egyik fél érdeke pontosan ellentétes a másik fél érdekével, tiszta vagy zéró összegü érdekkonfliktusról beszélünk. A két helyzet között helyezkednek el a harmadik típusba tartozó vegyes motívumú szituációk, melyekben a felek érdekei részben ütköznek, részben pedig megegyeznek (Kelley et al., 2003).

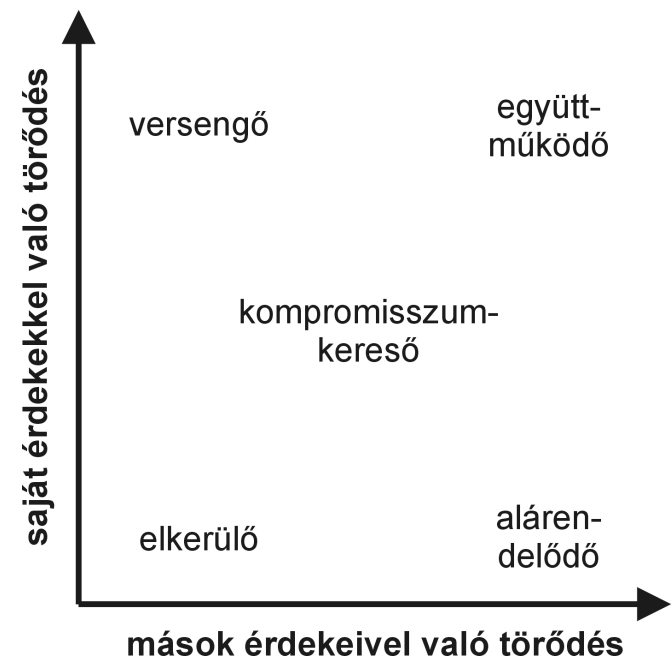

1. ábra: Pruitt és Rubin (1986, in: Gilbert et al., 1998) kettős-érdek modellje

Az érdekütközést tartalmazó konfliktusos helyzetek mögött meghúzódó alapdilemma megjelenítésére kiválóan alkalmas Pruitt és Rubin (1986, in: Gilbert, Fiske, Lindzey, 1998) kettős-érdek modellje (1. ábra), mely szerint az egyén egy érdekkonfliktus során egyaránt törekedhet a saját és a másik érdekeinek érvényesítésére. A modell fontos jellemzője, hogy e két szándék nem zárja ki egymást: független skálán helyezhető el. Ez azt jelenti, hogy az, hogy milyen mértékben törekszik az egyén saját érdekei érvényesítésére egy adott konfliktushelyzetben, független attól, hogy mindeközben mennyire veszi figyelembe mások érdekeit a megoldás kialakításában. Így az emberek adott érdekkonfliktus során választott viselkedése jól leírható a két skála egyidejü alkalmazásával, az egyes skálaértékek különböző kombinációival. A saját érdek érvényesítésére való törekvés a másik érdekének figyelmen kívül hagyásával versengő, míg annak figyelembe vételével együttműködő magatartásként értelmezhető. A saját érdekröl való lemondás a másik érdekének figyelembe vételével alárendelődő, anélkül viszont elkerülő viselkedésként definiálható. A saját és a másik fél érdekének közös, de csak részben történő figyelembe vétele a kompromisszumkereső stratégia.

A leggyakrabban a konfliktuskezelés és a tárgyalási helyzetek megértése során alkalmazott kettős-érdek modell jól párhuzamba állítható a versengéskutatás legújabb eredményeivel (Fülöp, 2008). Ezek az eredmények eltávolodnak a versengés-együttműködés klasszikusan polarizált értelmezésétől, ahol a saját érdek érvényesítése kizárta a másik érdekeivel való törődést és viszont. Mivel 
kutatásunkban tipikus kétszemélyes konfliktushelyzetekben mutatott viselkedési szándék kialakulását vizsgáltuk, tanulmányunkban a „versengés” kifejezést Pruitt és Rubin modellje alapján úgy értelmezzük, mint a saját érdek érvényesítésére való törekvést olyan módon, hogy közben figyelmen kívül hagyjuk a másik fél ugyanebben a helyzetben fennálló érdekeit, igényeit.

Pruitt és Rubin (1986, in: Gilbert, Fiske, Lindzey, 1998) kettős-érdek modelljével jól illusztrálható a zéró-összegű (tiszta érdekkonfliktusos) és a nem zéró-összegü (vegyes motívumú) kölcsönös függőségi helyzetek közötti különbség is. A zéróösszegü helyzetek során az elosztható erőforrások mennyisége előre meghatározott, és független a felek cselekedeteitöl. Ennek eredményeképpen nyerni csak a másik kárára lehet, és a felek minden igyekezetük ellenére sem tudnak a kompromisszumkereső stratégia által kínált lehetőségnél színvonalasabb, mindkettejük számára elönyös megoldást találni (Van Lange, De Dreu, 2000). Egy fix pénzjutalom elosztása zéró-összegü érdekkonfliktusnak tekinthető. A nem zéróösszegü kölcsönös függőségi helyzetek során a felek találhatnak olyan megoldásokat is, amelyekben úgy nyernek többet, hogy közben a másik nem veszít, vagy éppenséggel ő is sokat nyer. Az elosztható erőforrások mennyisége ezekben a szituációkban nincs előre lefixálva, az a résztvevők cselekedeteinek függvényében változhat. A nem zéró-összegü helyzetek nyújtanak teret a kettős-érdek modell jobb felső régiójában található, a tárgyalási szakirodalom által integratívnak (De Dreu, Weingart, Kwon, 2000) nevezett megoldásoknak, ezekben van lehetőség „meghaladni” a versengés-kompromisszumkeresés-alárendelődés egyenesét. Mivel azonban a valódi együttműködést eredményező megoldások megtalálása rendszerint komoly kognitív és társas erőfeszítéseket kíván meg az érdekkonfliktusban részt vevő egyénektöl, könnyen előfordulhat, hogy nem zéróösszegü helyzeteket is zéró-összegüként értelmeznek és oldanak meg (De Dreu, Weingart, Kwon, 2000). Ez az észleletekben megfigyelhető jelenség különösen érdekessé teheti a zéró-összegű társas konfliktushelyzetek elemzését annak ellenére, hogy valós, objektív módon zéró-összegünek tekinthető társas konfliktushelyzettel a mindennapok során ritkán találkozhatunk.

\section{A kölcsönös függőségi helyzetekben mutatott viselkedést befolyásoló tényezők}

Az utóbbi évtizedekben számos kutatás (pl. Deutsch, 1949; Kelley, Stahelski, 1970; Kuhlman, Marshello, 1975; Rapoport, 1976; Liebrand, Van Run, 1985; Yamagishi, 1988; Liebrand, Messick, Wilke, 1992; Rusbult, Van Lange, 1996; De Dreu, Boles, 1998; Horváth, 2000; Pietroni et al., 2008) foglalkozott azzal, hogy mitöl függ és hogyan jósolható be egy kölcsönös függőségi helyzet résztvevőinek az adott szituációban mutatott viselkedése. Grzelak (1995), illetve Van Lange és De Dreu (2000) alapján ezek a kutatások egy lehetséges csoportosítás szerint három fö tényezővel igyekezték magyarázni az emberek kölcsönös függőségi helyzetekben tanúsított magatartását: a normatív hatásokkal, a helyzetre jellemző szituatív tényezőkkel és az individuális különbözőségekkel. A normatív hatásokon azokat az általános, a társas helyzetek többségében elöhívódó normákat értjük, melyek megszabják, hogy hogyan illik, hogyan kell, hogyan szabad viselkedni az adott helyzetben. Szituatív tényezőkön a kifejezetten az adott helyzetre jellemző speciális sajátosságokat (pl. a felek közti kapcsolat, a kommunikáció lehetősége, a környezet 
bizonytalansága stb.) értjük, melyek befolyásolhatják a választott viselkedést. Individuális különbözőségeknek tekintünk bármely személyre jellemző tényezőt, mely megkülönbözteti a személyeket abban, hogy hogyan észlelnek egyes helyzeteket, és hogyan viselkednek bennük.

\section{Normatív hatások}

Egy adott helyzetben előhívódó, illetve abban észlelhető és értelmezhető normák kijelölhetik, hogy hogyan kell, hogyan szabad, hogyan illik viselkedni az érdekkonfliktus során. Egészen nyilvánvalónak tűnik például, hogy az ember nem kezd el vitatkozni egy várandós kismamával a villamoson azzal kapcsolatban, hogy az utolsó szabadon maradt ülöhelyet ki foglalja el (hacsak az illető nem maga is várandós kismama). Példánkban a viselkedésre ható erőteljes befolyásoló tényező a méltányosság normája, amely az érdekkonfliktusok során jelentkező nyereségek elosztásának igazságosságával foglalkozik (Deutsch, 1984). A méltányosság alapja lehet az egyenlőség (minden résztvevő ugyanakkora nyereséget kap), a teljesítmény (mindenki olyan arányban részesül a nyereségböl, amekkora mértékben annak elöállításában részt vett), és a szükséglet (akinek nagyobb szüksége van a nyereségre, jobban részesedik belöle - ez az elv képezi a társadalmi szolidaritás alapját is) (Deutsch, 1984). Egy ember érdekkonfliktus során mutatott magatartását a méltányosság normája mellett gyakran befolyásolják még többek között a viszonosság, a társas elkötelezettség és a társas felelősség normái is (Smith, Mackie, 2001).

Bár a normák többsége - és a felsorolt normák mindegyike - általános érvényü, a civilizált társas érintkezést alapjaiban szabályozó előírás, relevanciájuk észlelése és értelmezése - azaz annak eldöntése, hogy fontosak-e és mit is jelentenek az adott érdekkonfliktusban - természetesen egyaránt függ a szituáció jellemzőitől és a részt vevő felek egyéni sajátosságaitól.

\section{Szituatív tényezők hatása}

A normák többsége szituációtól függetlenül, általános érvénnyel van jelen társas érintkezéseink során, és interakcióink többségére hatást gyakorol. Vannak azonban olyan, helyzetre jellemző tényezők, melyek egyes szituációkra más módon vagy más erősséggel jellemzők, mint más szituációkra. Az egyes kölcsönös függőségi helyzetek erősen különbözhetnek egymástól, és különbözőségük jól kifejezhető bizonyos szituatív tényezők segítségével.

Az egyik ilyen szituatív tényező a kölcsönös függőségi helyzet szerkezete, melyet az határoz meg, hogy a felek céljai mennyire feleltethetőek meg egymásnak vagy mennyire ellentétesek, céljaik elérése milyen mértékben függ egymás és saját maguk cselekedeteitől, és ez a függés mennyire szimmetrikus vagy aszimmetrikus. A helyzet ezen jellemzői alapvetően befolyásolják, hogy az adott szituációban egy stratégia alkalmazása milyen eredményekhez vezethet (Kelley, Thibault, 1978, in: Kelley et al., 2003).

A kölcsönös függőségi helyzet kontextusa is hatással lehet a felek preferált magatartására. Kísérletes eredmények (Pillutla, Chen, 1999) bizonyítják például, hogy egy gazdasági kontextusba ágyazott érdekkonfliktus versengőbb (a saját 
érdeket előtérbe helyezőbb), míg egy nem-gazdasági kontextus együttműködőbb (mások érdekeit inkább figyelembe vevő) válaszokat aktivál.

Az érdekkonfliktust tartalmazó (vegyes motívumú vagy tiszta érdekkonfliktusos) kölcsönös függőségi helyzetek során nyilvánvaló, és számos vizsgálat által alátámasztott tény, hogy a konfliktusban részt vevő partner által követett stratégia jelentős befolyással bír az egyének viselkedésére. Ennek legjellemzőbb formája, hogy a partner versengő viselkedése versengést vált ki az ezzel a partnerrel kölcsönös függőségi helyzetbe kerülö egyénekből (Bixenstine, Wilson, 1969). Korábbi kutatások (Oskamp, 1971; Rapoport, 1976; Axelrod, 1984; McClintock, Liebrand, 1988) a partner stratégiáját követő, versengésre versengéssel, együttmüködésre együttműködéssel válaszoló szemet-szemért („tit-for-tat”) stratégia hosszú távon együttműködést kiváltó hatását igazolták. A résztvevők közötti kapcsolat, az egymás iránti bizalom az együttmüködő magatartásformák megjelenését valószínűsíti. Ehhez az szükséges, hogy a felek megbízzanak egymásban, és tudják, hogy a másik fél megbízik bennük (Kramer, Tyler, 1995). Az érdekkonfliktus szereplői között létrejövő releváns, azaz a konfliktus tárgyáról folytatott kommunikáció nagyban növeli az együttmüködő viselkedés megjelenésének valószínüségét (Wichmann, 1972, in: Grzelak, 2003; Dawes et al., 1977, in: Van Lange, De Dreu, 2000).

Az érdekkonfliktust tartalmazó kölcsönös függőségi helyzetben az egyén által megélt környezeti bizonytalanság ugyancsak befolyással lehet a választott viselkedésre. Roch és Samuelson (1997) vizsgálatai alapján a növekvő bizonytalanság (amely például a rendelkezésre álló erőforrás-tartalékok méretének ismeretlenségében mutatkozhat meg) növeli a versengő, saját érdeket előtérbe helyező magatartásformák megjelenésének valószínúségét.

Az érdekkonfliktust tartalmazó csoportos kölcsönös függőségi helyzetek során az együttműködő viselkedésformák választásának valószínüsége a csoportméret növelésével arányosan csökken (Kerr, 1989). A folyamat hátterében álló egyik lehetséges ok, hogy a csoportnagyság növekedésével az egyén egyre kevésbé érzi saját ráhatását a csoportmunka alakulására, anonimitást, a számon kérhetőség csökkenését élheti meg. Ezek az észleletek a csoportcélok elérésébe fektetett aktivitásának visszafogásához és a normaszegő (egyéni érdeket a csoportérdek elé helyező) viselkedéshez vezethetnek.

Mint látható, egy érdekkonfliktust tartalmazó kölcsönös függőségi helyzet számos olyan változóval jellemezhető, melyek az utóbbi évtizedek kutatásai során bizonyított módon hatást gyakorolnak a konfliktusban érintett felek viselkedésére.

\section{Individuális különbözőségek hatása}

Bár a felsorolt normatív és szituatív tényezők hatása az érdekkonfliktust tartalmazó kölcsönös függőségi helyzetekben mutatott viselkedésre meggyőzőnek tűnik, mindennapi tapasztalatainkból mégis érezhetjük, hogy az egyes emberek egészen eltérő módon viselkedhetnek ugyanazon szituatív és normatív változókkal leírható konfliktusok során. A kölcsönös függőségi helyzetekben mutatott viselkedés egyéni különbözőségeivel foglalkozó klasszikus megközelítés Messick és McClintock (1968) nevéhez füződik. Elméletük szerint az emberek elkülöníthetők egymástól aszerint, 
hogy a kölcsönös függőségi helyzetek többségében milyen megoldás elérésére törekszenek. Az egyén kölcsönös függőségi helyzet kimenetelére vonatkozó preferenciáját társas értékorientációnak nevezzük. Messick és McClintock (1968) a társas értékorientáció három fö típusát különítette el, melyek azóta is alapját képezik a témával foglalkozó kutatások jelentős részének: az együttmüködő (más néven: proszociális), az individualista és a versengő társas értékorientációt.

Az együttmüködő társas értékorientáció az együttes kimenetelek maximalizálására vonatkozó preferencia. Az együttmüködő társas értékorientációval jellemezhető személy a klasszikus megközelítés szerint egy érdekkonfliktus során az ideális megoldásnak azt tekinti, amely mindegyik fél számára a legnagyobb hasznot hozza (Messick és McClintock, 1968). A legújabb kutatási eredmények ugyanakkor azt igazolták, hogy a proszociális értékorientáció legfontosabb jellemzője sokkal inkább a felek eredményeinek egyenlöségére való törekvés, még akkor is, ha ez a közös haszon maximalizálásának rovására történik (Eek, Gärling, 2008). A proszociális orientációjú egyének viselkedésének alakításában így fontos szerepet játszhat az egyenlőség alapú méltányosság normája (Van Lange et al., 2007b).

Az individualista társas értékorientáció a saját haszon abszolút értelemben történő maximalizálására vonatkozó preferencia. Az individualista társas értékorientációjú személy egy érdekkonfliktus során a saját kimeneteleinek maximalizálására törekszik, és nem foglalkoztatják a másik fél eredményei. Olyan megoldásokat keres, amelyekkel ő a legjobban jár, függetlenül attól, hogy ez a másik fél számára kedvező vagy sem.

A versengő társas értékorientáció a saját haszon relatív értelemben vett maximalizálásának preferenciája. A versengő személy célja, hogy az érdekkonfliktus során többet nyerjen, mint a másik fél, függetlenül a nyereségek abszolút értékétől. $A$ versengés célja a másik legyőzése, még akkor is, ha ez az adott helyzetben nem több nyereségben, hanem kevesebb veszteségben fejeződik is ki.

A társas értékorientáció hagyományos, tipológia-szerü megközelítése alapján minden emberre jellemző egy olyan társas értékorientációs típus, mely a kölcsönös függőségi helyzetekben mutatott válaszait az esetek többségében meghatározza. Ezt az „alaptípust” színezhetik a szituáció különböző jellegzetességei, de a személy viselkedése végső soron mindig ezen alapvető értékorientáció befolyása alatt áll.

A társas értékorientációnak az érdekkonfliktust tartalmazó kölcsönös függőségi helyzetekben mutatott viselkedésre gyakorolt hatását számos vizsgálat eredménye bizonyította az utóbbi négy évtizedben (pl. Kelley, Stahelski, 1970; Kuhlman, Marshello, 1975; Maki, McClintock, 1983; Roch, Samuelson, 1997; Van Lange, Visser, 1999; Van Lange et al., 2007a). Ezen vizsgálatok túlnyomó többsége a kísérleti játszmák eszközét alkalmazta, vegyes motívumú helyzetekben. A kísérleti játszmák módszerének leggyakrabban alkalmazott formájában a felek érdekei pontok összegyűjtésében fejeződnek ki, és a kölcsönös függőségi helyzetek jellegzetességeit a pontgyüjtés szabályrendszere szimulálja. A vizsgálati személyek különböző válaszalternatívák közül választhatnak, melyek - a másik fél választásának függvényében - bizonyos pontszámot jelentenek saját maguk és a másik fél számára. A pontszámokban kifejezett nyereségek és veszteségek objektivitást és számszerüen vizsgálható eredményeket biztosítanak ezen kutatások 
számára. E kísérleti elrendezés jelentős hátránya azonban alacsony életszerüsége (De Dreu, Weingart, Kwon, 2000): a résztvevőknek a mindennapi élet összetett, számos szempont mérlegelését igénylő döntései helyett igen egyszerü, kifizetési mátrixokban leképezett, pontszámokban vagy pénzösszegben kifejezhető választásokat kell tenniük. Emellett a függőségi helyzet feloldását követő végeredmény is csupán pénzösszegek vagy pontok formájában jelenik meg a valóságos helyzet lélektani, anyagi és társadalmi hatásai helyett. Ezen sajátosságok megnehezíthetik a kísérleti játszmák eredményeinek mindennapi konfliktushelyzetekre történő általánosíthatóságát (Fülöp, 1995).

A társas értékorientáció mérésére alkalmazott vizsgálati eszközök ugyancsak a kísérleti játszmák logikáját követik. Ezek közül egy gyakran használt eszköz a Messick és McClintock (1968) alapján Van Lange és munkatársai (1997) által készített és publikált kérdőív. A kérdőív összesen 9 választási helyzet elé állítja a kitöltőt, melyek mindegyike három alternatívát tartalmaz. A választási helyzetek arra vonatkoznak, hogy egy pontelosztásos helyzetben mennyi pontot juttatna saját maga és egy hipotetikus ismeretlen másik fél számára. Az egyes alternatívák a klasszikus társas értékorientációs típusok válaszpreferenciáit szimulálják: van közöttük egy olyan elosztási változat, melyben a két fél közösen a legtöbb pontot éri el, és egyéni pontszámuk megegyezik (egyenlőség az eredményekben), egy olyan, melyben a válaszadó és a másik fél közötti nyereség különbsége a legmagasabb a válaszadó javára, és egy olyan, amellyel a kitöltő abszolút értékben a legtöbb pontot nyeri. Választásaik alapján a kitöltők bekategorizálhatók a három társas értékorientációs alaptípus (együttmüködő, versengő vagy individualista) valamelyikébe.

Összefoglalásul elmondhatjuk tehát, hogy az érdekkonfliktust tartalmazó kölcsönös függőségi helyzetekben mutatott viselkedést számos normatív, szituatív és individuális tényező befolyásolja, mely hatások igazolásával nagyszámú kutatás foglalkozott az utóbbi évtizedekben. Ezen kutatások jelentős része vizsgálati eszközül a kísérleti játszmák módszerét alkalmazta. Bár a kísérleti játszmák eredményeinek általánosíthatóságával kapcsolatban bizonyos szerzők kételyeket fogalmaztak meg (Fülöp, 1995; Boone, Declerck, Suetens, 2008; Pietroni et al., 2008; Van Beest, Van Kleef, Van Dijk, 2008), a módszer kétségtelen előnye, hogy objektív módon teszi vizsgálhatóvá az érdekkonfliktust tartalmazó kölcsönös függőségi helyzetekben mutatott viselkedést.

\section{A vizsgálat bemutatása}

Vizsgálati célunk az volt, hogy a klasszikus kísérleti játszmák kísérleti elrendezésétől eltérő, életszerű helyzeteket felidéző érdekkonfliktusokban megjelenő viselkedési szándék vizsgálatával tárjuk fel a szituációban megjelenő méltányossági viszonyoknak (mint normatív tényező) és a partner stratégiájának (mint szituatív tényező), valamint az egyéni különbségeknek a viselkedésre gyakorolt hatását. Amennyiben a kísérleti játszmákkal korábban kimutatott eredmények életszerü szituációk és nem pontban kifejezett válaszlehetőségek bemutatásával is megismételhetők, ez megerősítheti, hogy az adott tényezők valóban hatást gyakorolnak a hétköznapi konfliktushelyzetek során választott viselkedésre. Az életszerü szituációk alkalmazása megkönnyíti az olyan szituatív és normatív tényezők beépítését a helyzetbe, mint a méltányosság vagy a partner stratégiája, 
valamint segíthet abban, hogy a vizsgálati személy a döntési helyzetet életszerü konfliktushelyzetként élje meg.

\section{Hipotézisek}

Vizsgálati céljainkat a következő hipotézisek igazolásával igyekeztünk megvalósítani.

\section{1. hipotézis}

Minél jogosabbnak, méltányosabbnak észleli valaki a saját érdekeit egy tiszta érdekkonfliktus során, annál inkább jellemzö, hogy a saját érdekeit érvényesítő, versengő viselkedési szándékot fejez ki.

\section{2. hipotézis}

Minél versengőbbnek észleli valaki a másik fél stratégiáját a helyzetben, annál inkább jellemzö, hogy a saját érdekeit érvényesítő, versengő viselkedési szándékot fejez ki.

Első két hipotézisünkben egy-egy normatív, illetve szituatív tényezőt választottunk, mely hatással lehet az érdekkonfliktusok során megjelenő viselkedési szándékra. $A$ normatív tényezők közül a méltányosság normájára esett a választásunk, mint olyan normára, amely társas érintkezéseink többségét alapvetően befolyásolja (Fiske, 2006), a mindennapok érdekkonfliktusainak többségében jól értelmezhető és könnyen észlelhető. A szituatív tényezők közül a partner stratégiája került vizsgálati elrendezésünkbe. A partner stratégiája mind az eddigi kutatások (Bixenstine, Wilson, 1969; Oskamp, 1971; Axelrod, 1984; Rapoport, 1976; McClintock, Liebrand, 1988), mind hétköznapi élettapasztalataink alapján olyan szituatív tényező, amely amellett, hogy természetszerüen minden érdekkonfliktusban jelen van és észlelhető - alapvető befolyással bír a konfliktus résztvevőinek viselkedésére.

\section{3. hipotézis}

A versengő vagy individualista (proself) társas értékorientációval jellemezhető egyének versengőbb viselkedési szándékot mutatnak, mint a proszociális társas értékorientációval jellemezhető egyének.

\section{A vizsgálatban alkalmazott módszerek}

\section{A vizsgálati elrendezés felépitése}

A vizsgálat során a személyek egy hétköznapi érdekkonfliktusos helyzet négy típusú leírásával találkoztak. Az egyes, alaptörténetükben megegyező történet-típusok leírása abban különbözött egymástól, hogy a hipotetikus másik fél milyen stratégiát alkalmazott az érdekkonfliktus során (versengő vagy alárendelődő stratégia), illetve hogy az adott szituációban melyik fél érdeke (a vizsgálati személyé vagy a másik félé) volt méltányolhatóbb. E két változó segítségével összesen négy szituáció-típust képeztünk (zárójelben a szituációk kódjai): 1) A másik fél versengő stratégiát folytat és az ő érdeke méltányosabb (VM); 2) A másik fél versengő stratégiát folytat és a saját érdek méltányosabb (VS); 3) A másik fél alárendelődő stratégiát folytat és az ő 
érdeke méltányosabb (AM); 4) A másik fél alárendelődő stratégiát folytat és a saját érdek méltányosabb (AS).

A vizsgálati személyek először a szituáció egy-egy típusát olvashatták el. Mindegyik történet elolvasása után választaniuk kellett, hogy a megadott lehetőségek közül melyik megoldásra törekednének az adott helyzetben. Az elöre megírt válaszlehetőségek versengő, kompromisszumkereső és alárendelődő stratégiákat jelenítettek meg. Ezután a vizsgálati személyek újra elolvashatták a szituációt. A történet újbóli elolvasását követően azt kellett megállapítaniuk, hogy az adott érdekkonfliktusban milyennek észlelték a szituációban érintett hipotetikus másik fél stratégiáját (inkább a saját vagy inkább a másik érdekeinek érvényesítésével foglalkozik), illetve hogy milyennek észlelték a helyzet méltányossági viszonyait (inkább a saját érdeküket gondolják jogosabbnak, vagy inkább a másik fél elvárásait tartják méltányolhatóbbnak). A vizsgálatban alkalmazott szituációra egy példa (VS) az 1. mellékletben található. Egy személy a vizsgálat során a szituáció mind a négy típusával találkozott.

A kérdőívekben megírt konfliktushelyzetek zéró-összegü játszmák. Ennek a játszmatípusnak az a jellemzője, hogy a konfliktus alapját képező erőforrás fix, tehát amennyit nyer az egyik fél a konfliktus megoldását követően, szükségszerüen annyit veszít a másik fél (Grzelak, 1995). Ezekben a típusú játszmákban az egyéni érdekek együttes érvényesülésének maximális szintje a kompromisszumos megoldás, mely során a konfliktusban érintett feleknek le kell mondaniuk érdekeik egy részéröl, ha egy közösen elfogadott kimenetelt szeretnének elérni. Ezen feltételek mellett csak úgy tudnak a másik fél számára is megfelelő végeredményt találni, ha ezért áldozatokat hoznak. Azért választottunk zéró-összegű játszmát, mert bár a hétköznapok konfliktushelyzeteit gyakran meg lehet oldani úgy, hogy a résztvevök a kompromisszumos megoldásnál többet nyerjenek a szituációban, ennek a kimenetelnek a felkutatása nagy energia-befektetést kíván meg a felektől (a másik fél érdekeinek feltárása, alternatív javaslatok felkínálása). Ezt a folyamatot a kérdőíves kutatás formai jellemzői miatt lehetetlen volt szimulálni, mivel a válaszlehetőségeket elöre megfogalmaztuk a vizsgálati személyeknek, így nekik ezeket nem kellett energia-befektetések árán saját maguknak felkutatniuk. Ezért a proszociális viselkedési szándékot a másik fél érdekeinek figyelembe vételének mértékével jelenítettük meg. Minél inkább választ valaki az alárendelődő viselkedéshez közel álló, azaz a másik fél érdekeit szem előtt tartó viselkedést, annál inkább érvényesül magatartásában a proszociális viselkedési szándék, így a másik fél érdekeinek elősegítésének költségét a saját érdekekröl történő lemondás jelenti. Fontos látni azt is, hogy - zéró-összegü helyzetröl lévén szó - az erősen önérvényesítő viselkedéses szándék ebben a szituációban megegyezik a versengő szándékkal, mivel a saját érdek érvényesítése csak a másik érdekeivel ellentétben oldható meg.

A válaszlehetőségek egy 1-től 5-ig tartó skálának megfelelően lettek megfogalmazva. $A z$ 1-es válasz erősen versengő, a 2-es inkább versengő, a 3-as kompromisszumkereső, a 4-es inkább alárendelődő, az 5-ös pedig erősen alárendelődő viselkedési szándékot jelölt.

A másik fél észlelt stratégiájának (alárendelődő vagy versengő), illetve a szituációt jellemző méltányossági viszonyoknak (a másik érdeke méltányosabb vagy a saját érdek méltányosabb) a kifejezésére egy-egy hétfokú skála szolgált, melynek 
alacsonyabb értékei rendre az alárendelödöbb stratégiát, illetve a másik érdekeinek méltányosabb észleletét, míg magasabb értékei a versengő stratégiát, valamint a saját érdekek méltányosabb észleletét jelölték.

Az egyénekre jellemző társas értékorientáció mérésére Van Lange és munkatársai (1997) társas értékorientációs kérdőívét alkalmaztuk. Ebben a vizsgálati eljárásban a kísérleti személynek kilenc esetben kell döntést hoznia arról, hogy egy-egy kísérleti játszmához hasonló pontelosztási helyzetben milyen kimeneteleket preferálna a maga és a hipotetikus másik fél számára. Minden fordulóban három alternatíva áll a személy rendelkezésére, melyek választása megfeleltethető az együttműködő, versengő és individualista társas értékorientációnak. Ha a vizsgálati személy hat konzisztens, egy típusba eső választ ad a kérdőívben, bekategorizálható az adott társas értékorientációs típus valamelyikébe. Hat konzisztens válasz hiányában a kérdőív a személyt nem kategorizálhatóként jelöli. A kérdőívre adott válaszok alternatív dichotóm kategorizálására ad lehetőséget, ha a legalább hat konzisztens együttműködő választ adó személyeket proszociális, a többi személyt pedig proself társas értékorientációs típusba soroljuk. Az eredmények értelmezése során a proszociális-proself kategóriák használatakor ezt a módszert alkalmaztuk.

\section{A kérdőív felvételének körülményei}

A kérdőíveket 5 fordulóban vettük fel. Az első négy fordulóban az érdekkonfliktusos szituáció egy-egy típusát adtuk a kísérleti személyeknek. A kísérleti személyeknek elöször az általuk preferált kimenetelnek leginkább megfelelő viselkedésként megfogalmazott választ kellett megjelölniük, majd ezt követően a szituáció leírása alapján a másik fél általuk észlelt stratégiáját és a méltányossági viszonyokat kellett megállapítaniuk. Az ötödik, záró fordulóban a kísérleti személyeket a társas értékorientációs kérdőív kitöltésére kértük fel. Két forduló között átlagosan 2-3 nap telt el: így kívántuk elkerülni, hogy a különböző szituáció-típusokra adott válaszok befolyásolják egymást. A kísérleti személyek megkeresése és a kérdőív felvétele részben személyesen, részben pedig elektronikus formában (e-mail váltások segítségével) történt.

\section{A minta általános jellemzői}

A vizsgálatban összesen 98 személy vett részt. A kérdőívek felvételekor 69 fő esett 18-24 év közötti kategóriába, ami a minta 70,4\%-át teszi ki. 16 személy tartozott 25 és 34 év közötti korcsoportba (a minta 16,3\%-a), 9 személy életkora volt 35 és 44 életév között $(9,1 \%)$ és 4 személy 45 és 54 életév közötti $(4,2 \%)$. A vizsgált minta egyetemi, főiskolai tanulókból és dolgozókból állt: a 98 fős mintából 69 személy tanul valamilyen felsőfokú intézményben (a minta 70,4\%-a), 29 személy pedig munkavállaló $(29,6 \%)$. A nemek szerinti megoszlás alapján a vizsgált mintában 77 fö volt nő $(78,6 \%), 21$ fö pedig férfi $(21,4 \%)$.

\section{Az eredmények bemutatása}

Elővizsgálat a manipulált változók észleletének ellenőrzésére 
Mielőtt a vizsgálat során megfogalmazott hipotéziseinket teszteltük volna, a vizsgálati konstrukció ellenőrzését végeztük el. Arra voltunk kíváncsiak, hogy a vizsgálati személyek valóban annak megfelelően észlelték az egyes szituációkban a partner stratégiáát és a méltányossági viszonyokat, amilyennek a manipulált leírások segítségével mi igyekeztünk alakítani azokat. Mivel a vizsgálat során egy személytöl egy változóban összesen négy adat származott, melyet a négy különböző szituációtípusban válaszolt, az észleletek átlagainak összehasonlításához az ismételt mérések eljárását alkalmaztuk.

Az eredmények szignifikáns különbségeket mutattak mind a szituációra vonatkozó méltányossági viszonyok $(F=206,550$; hyp.df $=1$; error $d f=96 ; p<, 01)$, mind a partner stratégiája $(F=334,440$; hyp. $d f=1$; error $d f=96 ; \quad p<, 01)$ esetében. A vizsgálati személyek elvárásainknak megfelelöen észlelték az egyes változókat a különböző szituáció-típusokban (észlelt méltányosság: AM és VM szituációk átlaga - 3,56; AS és VS szituációk átlaga - 5,66; észlelt partneri stratégia: AM és AS szituációk átlaga: 3,70; VM és VS szituációk átlaga: 5,94). Az eredmények még egy fontos dolgot alátámasztottak: a helyzetek nem bizonyultak túlságosan „erősnek” (hétfokú skáláról lévén szó), így nem állt fenn a veszélye annak, hogy szélsőségesen erős szituatív, illetve normatív változókkal egyértelmüen befolyásoljuk a viselkedési szándékot, evidens eredményeket produkálva.

\section{A hipotézisek ellenörzése}

Három hipotézisünk igazolására az ismételt mérések statisztikai eljárásával összehasonlítottuk az egyes szituáció-típusokban a vizsgálati személyek által választott viselkedési intenciók átlagértékeit, a modellbe személyek közötti faktorként beépítve a társas értékorientációt.

Az eljárás szignifikáns különbséget mutatott a vizsgálati személyek viselkedési szándékaiban az eltérő méltányossági viszonyokkal jellemezhető (1. hipotézis; $\mathrm{F}=75,784$; hyp.df=1; error $\mathrm{df}=96$; $\mathrm{p}<, 01)$, valamint az eltérő partneri stratégiával jellemezhető (2. hipotézis; $F=42,772$; hyp.df $=1$; error $d f=96 ; p<, 01$ ) szituációk között. A társas értékorientáció hatását (3. hipotézis) a viselkedési szándékra sem föhatásként, sem interakciós hatásként nem sikerült kimutatni.

Az egyes szituációk-típusokban megfogalmazott viselkedési szándékok átlagai a 2., 3. és 4. ábrán láthatók (az alacsonyabb értékek versengőbb viselkedési szándékot jelölnek). 


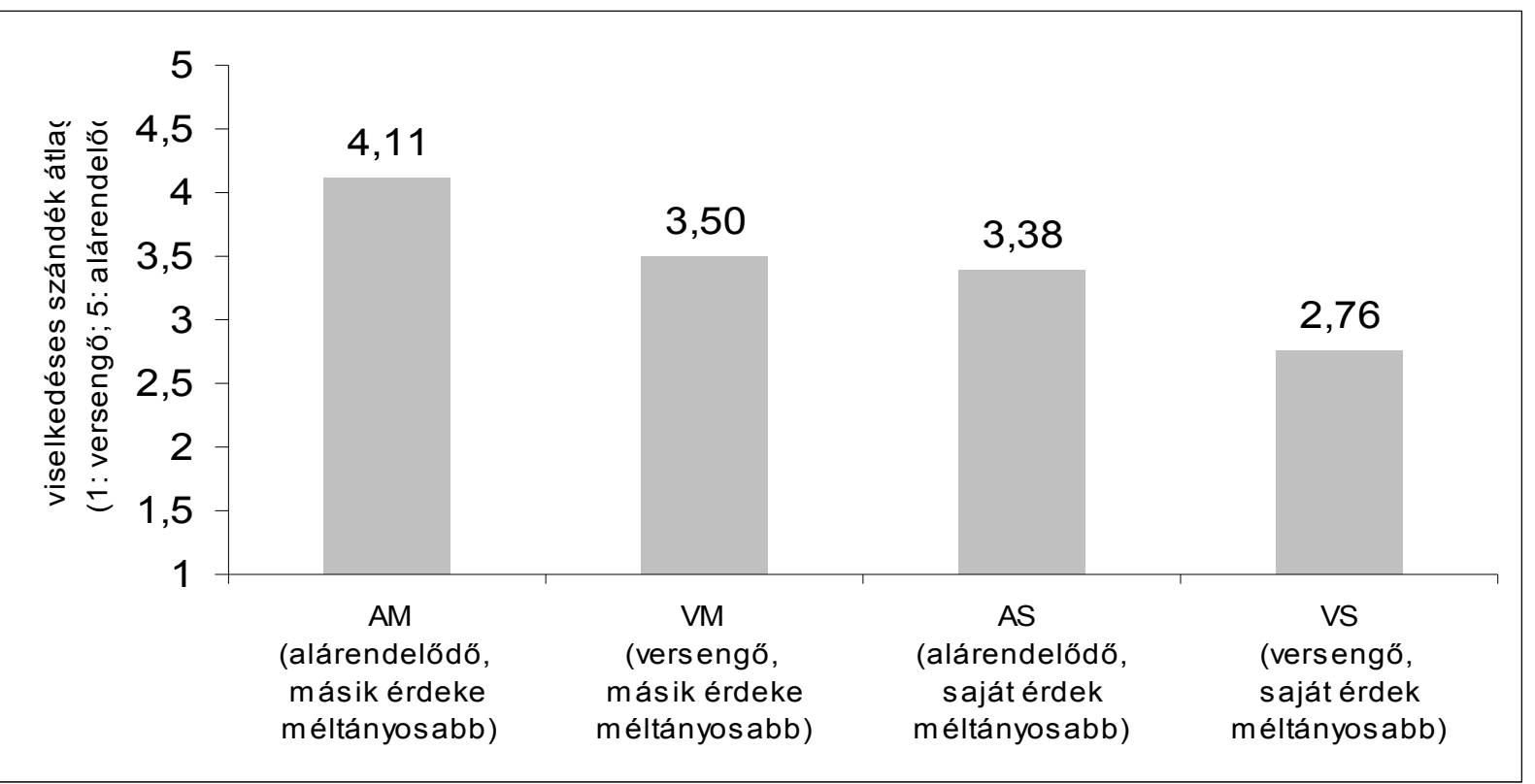

2. ábra: Az egyes szituáció-típusokban megfogalmazott viselkedési szándékok átlagai

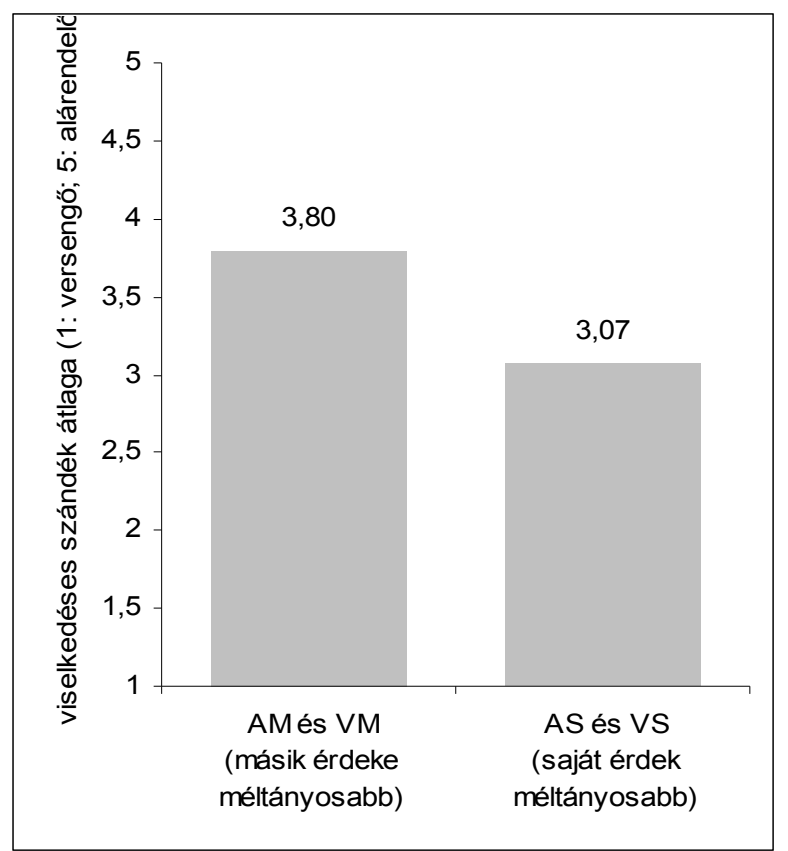

3. ábra: A méltányossági viszonyok alapján megkülönböztethető 2-2 szituációtípusban megfogalmazott viselkedési szándékok átlagai

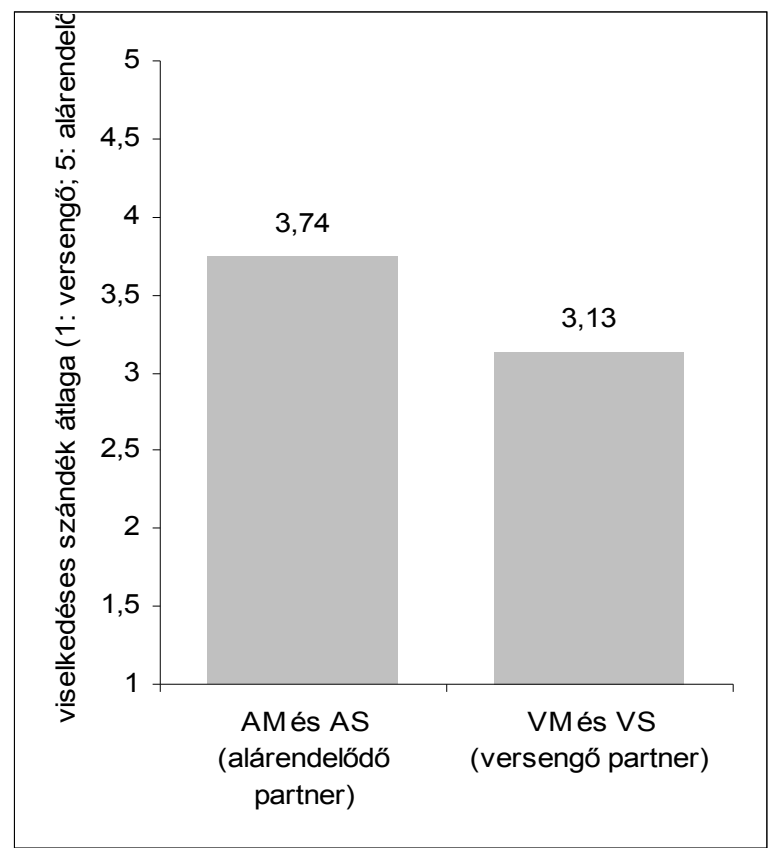

4. ábra: A partner stratégiája alapján megkülönböztethető 2-2 szituációtípusban megfogalmazott viselkedési szándékok átlagai

Mivel nem sikerült igazolnunk a társas értékorientáció 3. hipotézisben feltételezett hatását a viselkedési szándékra, az eredetileg megfogalmazott csoportosítástól (proself és proszociális társas értékorientáció) eltérve a Van Lange és munkatársai (1997) által publikált kérdőív eredeti instrukciója alapján négy csoportot (proszociális, individualista, versengő, nem kategorizálható) különítettünk el a kérdőív eredményei alapján. Az így lefuttatott statisztikai eljárás az előzőhöz hasonlóan nem mutatta ki a társas értékorientáció szignifikáns hatását a viselkedési szándékra (viselkedéses szándékok átlaga négyes csoportosítás során: proszociális - 3,43; individualista 3,43 ; versengő - 3,56; nem kategorizálható - 3,42; dichotóm kategóriák esetén: proszociális $-3,43$; proself $-3,45$ ). 
Miután számos korábbi vizsgálat (pl. Kelley, Stahelski, 1970; Kuhlman, Marshello, 1975; Maki, McClintock, 1983; Roch, Samuelson, 1997; Van Lange, Visser, 1999; Van Lange et al., 2007a) igazolta, hogy az emberek között léteznek individuális különbségek az érdekellentétet tartalmazó kölcsönös függőségi helyzetekben mutatott viselkedésükben, 3. hipotézisünk igazolásának sikertelensége meglepőnek mondható. Az eredmények alapján bizonyítást nyert, hogy tiszta érdekkonfliktusok során a szituációra jellemző, jól észlelhető, de nem szélsőségesen erős változók, mint a helyzet méltányossági viszonyai és a partner stratégiája, szignifikáns hatást gyakorolnak a résztvevők viselkedési szándékaira, ugyanakkor a vizsgálat során a társas értékorientációnak nem volt erre hatása. Mivel igen valószerütlennek tünik, hogy az emberek nem mutatnak egyéni különbözőségeket viselkedési szándékaik kialakításában, két valószínú magyarázat lehet az eredményekre. Egyrészt lehetséges, hogy a társas értékorientáció mérésére szolgáló eszköz megbízhatósága nem megfelelö, így ebben a vizsgálatban, jelen mintanagyság esetén nem produkált szignifikáns eredményeket. Másrészt az is elképzelhető, hogy a vizsgálati konstrukciónkban alkalmazott életszerü helyzetek és az ezekbe ágyazott manipulált változók olyan vizsgálati környezetet alkottak, melyben nem ismétlődött meg a társas értékorientáció korábban jellemzően kísérleti játszmák során kimutatott hatása a viselkedési szándékra.

Annak érdekében, hogy igazoljuk, az emberek között léteznek individuális különbözőségek viselkedési szándékaik megválasztásában tiszta érdekkonfliktusok során, hierarchikus klaszteranalízis segítségével kíséreltük meg a teljes mintát az egyes szituációkban megjelölt viselkedési szándékok, valamint az ezen szituációkban megfogalmazott észleletek (méltányosság és partneri stratégia) felhasználásával csoportokra osztani. Feltételezésünk az volt, hogy a mintában jól elkülöníthető csoportok találhatók, melyek egymástól eltérően észlelik a méltányossági viszonyokat és a partner stratégiáját az egyes helyzetekben, és egymástól eltérő viselkedési szándékot fogalmaznak meg az egyes szituációk során.

A klaszteranalízis eredménye alapján a mintát három, egymással közel azonos méretü $(\mathrm{N} 1=30 ; \quad \mathrm{N} 2=37 ; \quad \mathrm{N} 3=31)$ csoportra bontottuk. A klaszterek észlelési stílusukban és viselkedési szándékaikban való eltéréseit a korábbi hipotéziseink során alkalmazott ismételt mérések eljárásával ellenőriztük. A modellbe egyének közti változóként vettük be a klasztertagságot.

Az eredmények a következőket mutatták.

a) A klaszterek egymástól szignifikánsan különböztek abban, hogy milyen módon észlelték a helyzetben megjelenő méltányossági viszonyokat összességében $(\mathrm{F}=21,534 ; \mathrm{df}=2 ; \mathrm{p}<, 01)$, és a manipulált méltányosság változójával interakcióban egyaránt $(F=32,502$; hyp. $d f=2$; error $d f=95 ; p<, 01)$.

b) A klaszterek egymástól szignifikánsan különböztek abban, hogy milyen módon észlelték a helyzetben megjelenő partneri stratégiát összességében $(F=6,30 ; d f=2$; $p<, 01$ ), de nem mutattak szignifikáns különbséget a partneri stratégia változójával interakcióban. 
c) A klaszterek egymástól szignifikánsan különböztek abban, hogy milyen viselkedési szándékot fogalmaztak meg a két manipulált változó alapján létrehozott négy szituáció-típusban, azaz a klasztertagság $\mathrm{x}$ méltányossági viszony $\mathrm{x}$ partneri stratégia hármas interakciója szignifikánsnak bizonyult $(F=5,262$; hyp.df=2; error $d f=95 ; p<, 01)$.

Az 5. ábrán látható, hogy az 1 . klaszter mind a másik érdekeinek méltányosságával manipulált ( $A M$ és $V M$ ), mind a saját érdekek méltányosságával manipulált ( $A S$ és VS) helyzetben inkább érezte a másik fél érdekeit méltányosabbnak (alacsonyabb érték), mint a 3. klaszter. A 2. klaszter pedig mindkét másiktól eltérő módon, a manipulációhoz igazodóbb, szituációnként egymástól távol eső észleleteket fogalmazott meg: amikor a manipuláció szerint a másik fél érdekei méltányosabbak voltak, a másik két klaszternél ezt erősebben észlelte (alacsonyabb érték), míg az ellenkező helyzetekben ez a klaszter észlelte a leginkább a saját érdekeket méltányosabbnak.

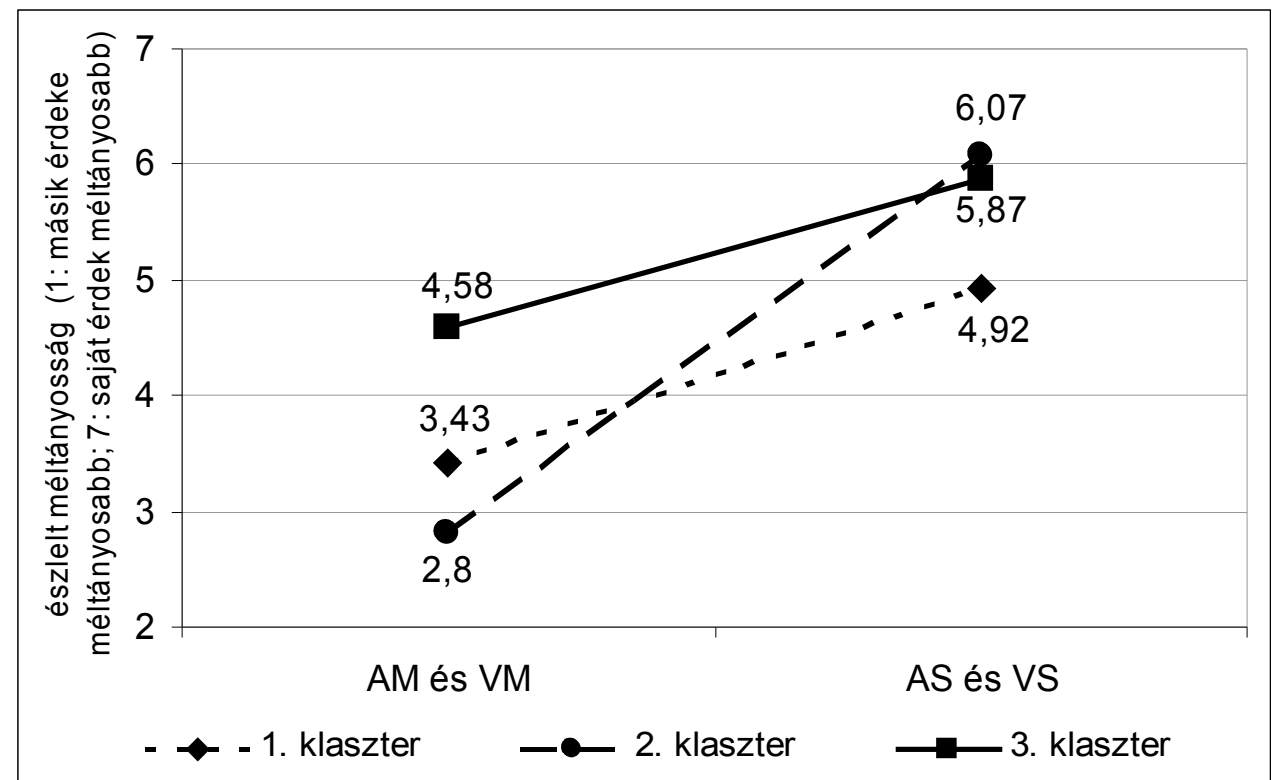

5. ábra: Az egyes klaszterek által észlelt méltányosság a méltányossági viszonyok szempontjából manipulált $2 \times 2$ szituációban

A partner észlelt stratégiája tekintetében a klaszterek csak kismértékben különböztek abban, hogy milyennek észlelték a másik felet, míg a méltányosság észleleténél megfigyelhető interakciós hatás nem jelentkezett (6. ábra). 


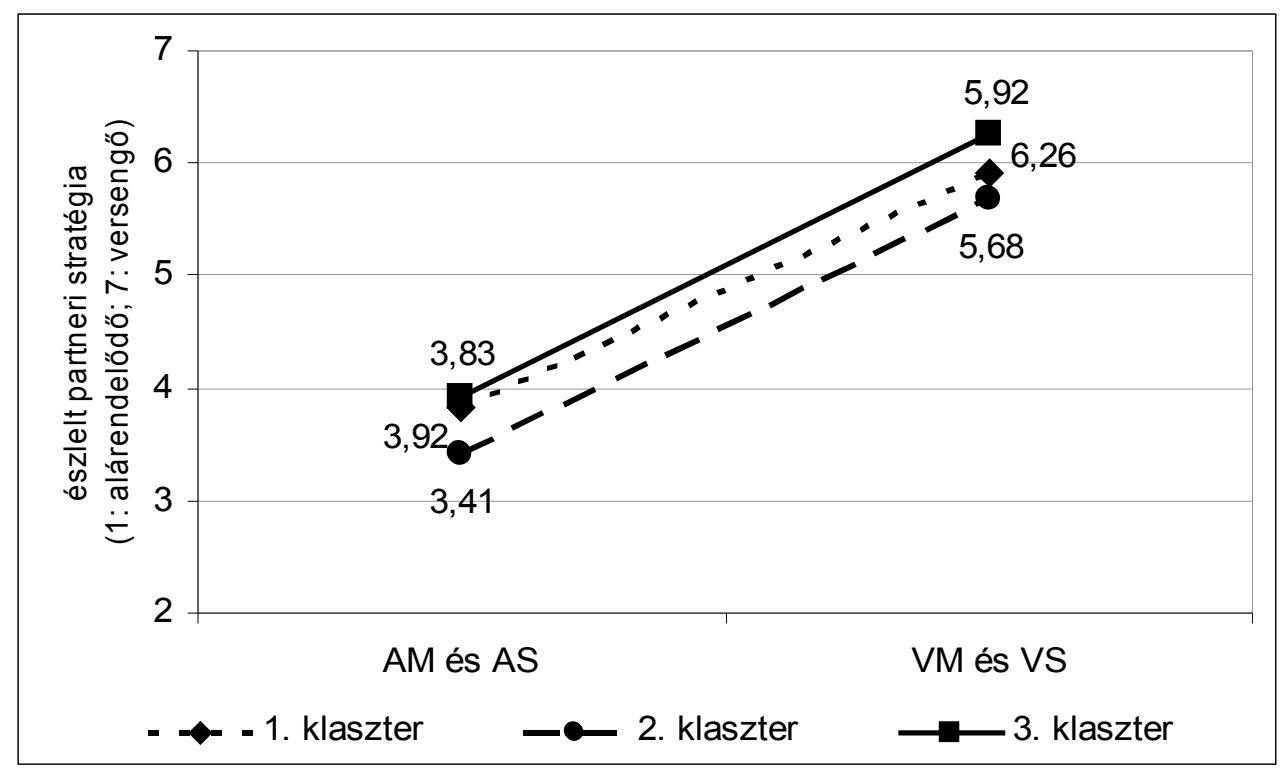

6. ábra: Az egyes klaszterek által észlelt partneri stratégia a partner stratégiájának szempontjából manipulált 2x2 szituációban

A viselkedési szándékok megfogalmazásában a klaszterek között jelentős különbségeket figyelhetünk meg: az egyes klaszterek eltérö profillal rendelkeznek a négy szituációban adott válaszaik tekintetében. Ezeket a profilokat a 7. ábráról olvashatjuk le.

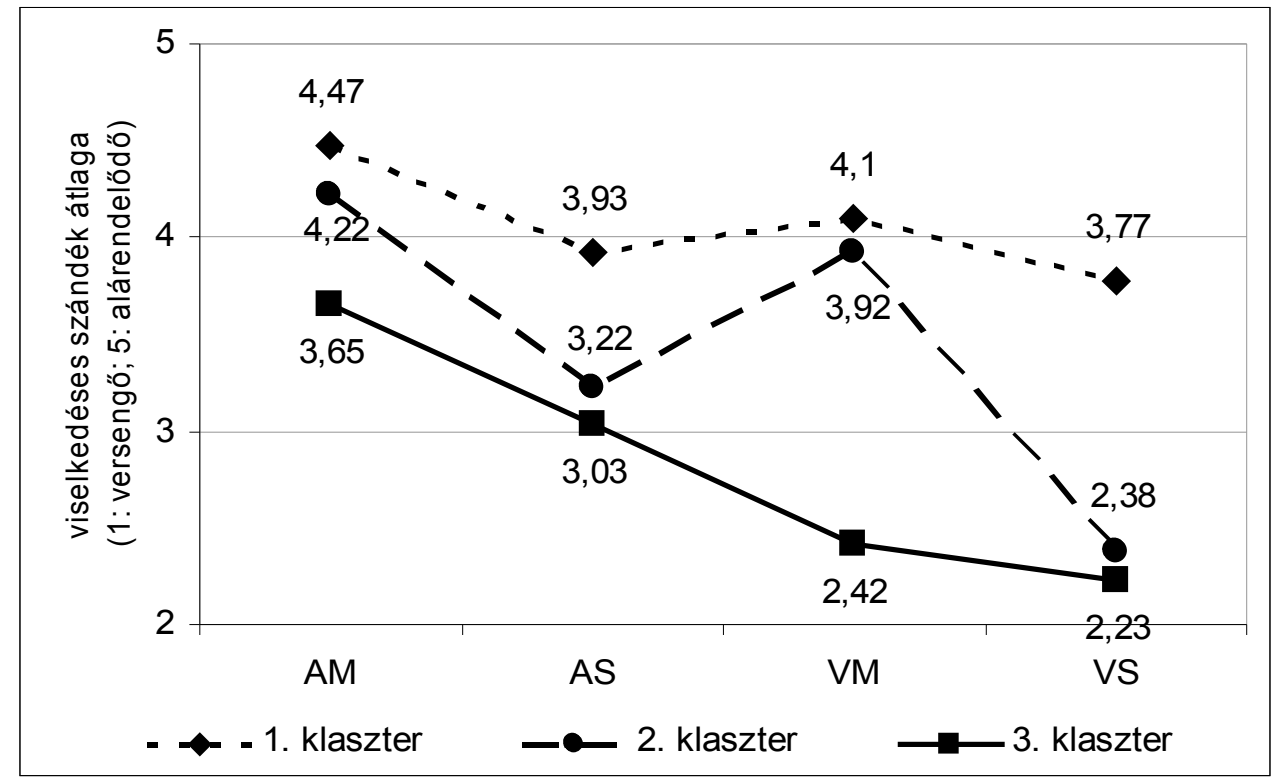

7. ábra: Az egyes klaszterek által a négy szituáció-típusban megfogalmazott viselkedési szándék

A 7. ábrán látható, hogy az 1. klaszter a két másik klaszternél alárendelődőbb (magasabb érték) válaszokat adott mindegyik szituációban, bár a 2 . klasztertöl való eltérés az AM és a VM szituációban minimális. A 3. klaszter a két másik klaszternél versengőbb válaszokat adott mindegyik szituációban, de a 2 . klasztertöl való eltérés az AS és a VS szituációban minimális. Az is leolvasható az ábráról, hogy az 1 . klaszter viselkedési szándékai sokkal kevésbé mutatnak változatosságot a négy 
szituáción keresztül, mint a 2. vagy a 3. klaszteré. Míg a 2. és a 3. klaszter jól érzékelhetően igazítja a viselkedési szándékait a szituáció jellegzetességeihez, az 1. klaszter ezt csak minimális mértékben teszi meg. A 2. és a 3. klaszter egymástól egyrészt szándékaik versengő jellegében különböznek (a 3. klaszter versengőbb, mint a 2.), másrészt pedig abban, hogy mely változókhoz igazítják inkább viselkedési intencióikat. A 2. klaszter a méltányossági viszonyokra érzékenyebb: a másik érdekeinek méltányossága esetén inkább alárendelődő, a saját érdek méltányossága esetén pedig versengőbb szándék jellemzi. A klaszteren belül elvégzett ismételt mérés során a méltányosság $F$ értéke 87,046 ; hyp.df $=1$; error $d f=35,00 ; p<, 01$, a partneri stratégiáé pedig $F=22,077$; hyp.df $=1$; error $d f=35,00 ; p<, 01$. A 3. klaszter inkább a partner stratégiájának fényében alakítja saját szándékait, melyet „színez” a méltányossági viszonyok észlelete (partneri stratégia: $F=23,888$; hyp.df=1; error $d f=29,00 ; \quad p<, 01$; méltányosság: $F=9,573$; hyp. $d f=1$; error $d f=29,00 ; \quad p<, 01)$. Alárendelődő partnerrel szemben kevésbé verseng, mint versengő partnerrel szemben, ezen belül pedig a saját érdekek méltányossága ugyancsak hozzájárul a versengő szándék kialakulásához.

A három klaszter tehát a helyzet észleletében és a viselkedési intenciók tekintetében jellegzetes különbözőségeket mutat.

Az 1. klaszter „barátságosan” észleli a helyzetet, melyben a másik két klaszternél inkább látja a másik fél érdekeit méltányosnak. A partner stratégiáját a másik két klaszterhez hasonlóan objektíven, a manipulációnak megfelelően észleli. Viselkedési szándékait azonban kevésbé igazítja a helyzethez, mint a másik két klaszter: válaszai e tekintetben a legkisebb különbséget mutatják a szituáció-típusok között.

A 3. klaszter „egocentrikusan” észleli a helyzetet, melyben a másik két klaszternél inkább látja saját érdekeit méltányosnak. A partner stratégiáját a másik két klaszterhez hasonlóan objektíven, a manipulációnak megfelelően észleli. Viselkedési szándékait elsősorban a partner észlelt stratégiájához, másodsorban pedig a helyzetben észlelt méltányossági viszonyokhoz igazítja. Versengő partnerrel szemben inkább törekszik versengésre, mint alárendelődővel szemben, és ezen belül a saját érdekeinek méltányossága erősíti versengő szándékát.

A 2. klaszter a helyzetet a másik kettőnél, úgy tűnik, „objektívebben”, de legalábbis differenciáltabban és egységes irányú torzítástól mentesen észleli. Ebben elsősorban a méltányosság észlelete során különbözik a másik két klasztertöl, mivel a partner stratégiáját azokhoz hasonlóan objektíven észleli. Viselkedési szándékát erősen igazítja a helyzethez: elsősorban a méltányossági viszonyokhoz (a saját érdek méltányossága erősíti versengését), másodsorban pedig a partner stratégiájához (versengő partnerrel szemben versengőbb szándékai vannak). Összességében a 2. klaszter a leginkább helyzethez igazodó, legdifferenciáltabb mind a helyzet észleletében, mind az annak hatására kialakított viselkedési intencióiban.

Mivel eredeti hipotéziseink között szerepelt, hogy az egyének közti individuális különbözőségek mögött a társas értékorientáció konstruktuma áll, Chi-négyzet próbával ellenőriztük, hogy a klaszterek tagjai különböznek-e egymástól társas értékorientációs típusaikban. Mind a klasszikus négyes tagolás (versengő, individualista, együttmüködő, nem kategorizálható), mind pedig a proself-proszociális megkülönböztetés alkalmazásával elvégeztük az eljárást, de sem az elöbbi (Chi- 
négyzet $=2,876 ; d f=6 ; p=, 824$ ), sem az utóbbi (Chi-négyzet $=, 246 ; d f=2 ; p=, 884$ ) esetében nem kaptunk szignifikáns eltérést az egyes klaszterek között. A klaszterek nem különböztek tagjaik társas értékorientációjában.

\section{Következtetések}

A bemutatott eredmények részben támasztották alá előzetes hipotéziseinket. Az első két hipotézis igazolásának összefoglalásaként elmondhatjuk, hogy az észlelt méltányossági viszonyok és a partner észlelt stratégiája szignifikáns kapcsolatot mutatott a vizsgálati személyek viselkedésre vonatkozó szándékaival. A vizsgálati személyek feltételezéseinknek megfelelő módon versengőbb viselkedési szándékot mutattak akkor, ha a saját érdekeiket észlelték jogosabbnak, méltányosabbnak a helyzetben, illetve akkor, ha a partner viselkedését versengőnek észlelték.

A harmadik hipotézisben megfogalmazott feltételezést, miszerint a versengő vagy individualista (proself) társas értékorientációval rendelkező egyének versengőbb viselkedési szándékot mutatnak, mint a proszociálisok, nem sikerült igazolnunk. Mivel korábbi vizsgálatok kísérleti játszmák alkalmazásával számos esetben mutattak ki összefüggést a társas értékorientáció és a viselkedés között, lehetséges, hogy a fenti eredmény oka az eltérő vizsgálati konstrukcióban keresendő. Egy lehetséges magyarázatként adódna, hogy a vizsgálatunkban megjelenő életszerü helyzetek túlságosan erős, szituációból eredő változókat tartalmaztak, azaz a szituáció hatása annyira erősen érvényesült, hogy elnyomta az emberek közötti egyéni különbségeket a viselkedési szándék megfogalmazódásakor. Ezt a feltételezést azonban két okból is elvethetjük. Egyrészt a manipulációk ellenőrzése során igazolást nyert, hogy a szituációk nem szélsőségesen erősek: 1-7-es skálán mérve a beépített manipulált változók közül a méltányossági viszony átlagértékei a két típusú helyzetben 3,56 és 5,65 , a partner stratégiájának átlagértékei pedig 3,70 és 5,93. Másrészt pedig nem igaz az az állítás, hogy a vizsgálati személyek nem különböztek egymástól jelentősen viselkedési szándékaikban az egyes szituációtípusokon belül: az elvégzett klaszteranalízis segítségével egyértelműen azonosítottunk három, egymástól szignifikánsan eltérő viselkedési szándékkal rendelkező csoportot. Az eredmények alapján nehéz választ adni arra, hogy a kimutatott individuális különbözőségek a viselkedési szándékokban miért nem mutattak kapcsolatot a társas értékorientációval. Lehetséges, hogy a társas értékorientációt mérő eljárás (Van Lange és munkatársai, 1997) kísérleti játszmákhoz hasonlatos elrendezése az oka annak, hogy az eljárással mért társas értékorientáció - miközben számos korábbi kutatás igazolta kapcsolatát kísérleti játszmákban mért viselkedéssel - nem mutatott összefüggést az életszerü helyzetekhez hasonló szituációkban megfogalmazott viselkedési szándékkal. Ennek a feltételezésnek az igazolása azonban további célirányos kutatásokat igényel. Ugyanakkor az eredmények a versengéskutatásban tapasztalható paradigmaváltással (Fülöp, 2008) párhuzamosan arra is rámutathatnak, hogy a társas értékorientáció klasszikus hármas kategorizációja (együttműködőindividualista-versengő), és ezen kategóriák erőteljes elkülönítése nem megfelelő az emberek valós társas helyzetekben megfogalmazott viselkedési szándékainak megértéséhez. 
Mivel feltételeztük, hogy a harmadik hipotézis be nem igazolódásának ellenére is van vagy vannak olyan egyénre jellemző változó(k), melyek befolyásolják, hogy az emberek ugyanazon helyzetben milyen észleleteket és milyen viselkedési szándékot alakítanak ki, a mintánkban klaszteranalízis segítségével kerestünk viselkedési szándékukban és észlelési stílusukban eltérő csoportokat.

Eredményeink igazolták előzetes várakozásainkat. Három, egymástól viselkedési szándék és észlelési stílus terén szignifikánsan eltérő csoportot sikerült azonosítanunk. A csoportok szignifikáns különbséget mutattak a méltányossági viszonyok észlelete, valamint a viselkedésre vonatkozó szándék megfogalmazása tekintetében, míg a partner stratégiáját többé-kevésbé hasonlóan (és az eredeti manipulációnak megfelelően) észlelték. Az 1. csoport a helyzetekben a másik kettőnél átlagosan méltányosabbnak ítélte a másik fél érdekeit, és viselkedési szándékai is mindkét csoporthoz képest alárendelődőbbek voltak. Emellett szándékait a másik két csoportnál kisebb mértékben igazította az eltérő helyzetekhez. Összességében az „alárendelődő” címkével láthatjuk el a csoportot: olyan embereket tartalmaz, akik a helyzeteket hajlamosak a másik javára méltányosnak ítélni, és összességében függetlenül az egyes szituációk eltérő jellegétől, gyakran rendelik alá saját érdeküket a másik fél akaratának. Az értelmezés során érdemes a 3. csoportot a 2. elé venni. A 3. csoport az elsővel éppen ellentétesen a másik kettőnél átlagosan kevésbé ítélte méltányosnak a másik fél érdekeit, és viselkedési szándékai mindkét csoporthoz képest versengőbbek voltak. Szándékait igazította a helyzetek eltérő sajátosságaihoz, ezen belül is elsősorban a partner stratégiájához, és csak másodsorban a méltányossági viszonyokhoz. A csoportot a „versengő” címkével láthatjuk el: olyan embereket tartalmaz, akik a helyzetben gyakran inkább a saját érdekeiket látják jogosabbnak, és viselkedési szándékuk jellemzően versengő, de ez a versengés erősebb egy versengő partnerrel szemben, valamint olyan helyzetekben, amikor saját érdekeiket különösen méltányosabbnak tartják a másik fél érdekeinél. A 2. csoport az előző kettőtől nem elsősorban viselkedési szándékának vagy észleleteinek az átlagos értékében különbözik. A jelentős különbséget az adja, hogy a másik két csoportnál sokkal differenciáltabban észleli a helyzetek méltányossági viszonyait, és azokban sokkal differenciáltabb viselkedési szándékot fogalmaz meg. A csoportot az „igazító” címkével láthatjuk el, mivel mind a méltányosság, mind a partneri stratégia észleletében pontosan követi az eredeti manipulációt (azaz „objektívnek” mondható), és ennek megfelelően viselkedési szándékai is igen eltérőek az egyes szituációtípusok között. Szándékait elsősorban a méltányossági viszonyokhoz igazítja, de a partneri stratégia is befolyásolja viselkedési szándékának kialakulását. Azokban a helyzetekben a legversengőbb, amikor saját érdekeit méltányosabbnak, a partner viselkedését pedig versengőnek észleli: ilyenkor a „versengő” csoporthoz hasonló viselkedési szándékot mutat. Azokban a helyzetekben a leginkább alárendelődő, amikor a másik fél érdekeit méltányosabbnak, a partnert pedig alárendelődőnek észleli: ilyenkor az „alárendelődő” csoporthoz hasonló viselkedési szándékot mutat. A 2. csoport erősen a helyzethez igazodó viselkedési szándékából azt a fontos következtetést is levonhatjuk, hogy egyetlen szituáció nem feltétlenül elegendő ahhoz, hogy megkülönböztessük egymástól az eltérő konfliktuskezelési stratégiával rendelkező egyéneket. A 2. csoport viselkedése az „AM” szituációban nem különbözik az 1. csoportétól (de mindkettőjüké eltér a 3. csoportétól), míg „AS” szituációban nem különbözik a 3 . csoportétól (de mindkettőjüké eltér az 1. csoportétól). 


\section{Összefoglalás}

Tanulmányunkban az emberek tiszta érdekkonfliktusok során mutatott viselkedési szándékainak vizsgálatával foglalkoztunk. Arra voltunk kíváncsiak, hogy a helyzetre jellemző méltányossági viszonyok, mint normatív tényező, a partner stratégiája, mint szituatív tényező, és a válaszadó társas értékorientációja, mint egyéni tényező hogyan befolyásolják a személy viselkedésre vonatkozó szándékának kialakulását. Ez utóbbin azt értettük, hogy a személy szándékában milyen mértékben jelenik meg a másik érdekeinek figyelembe vétele, és milyen mértékben saját érdekeinek érvényesítése. Hipotéziseink teszteléséhez egy hétköznapi érdekkonfliktus leírását alkalmaztuk, melynek elolvasása után a vizsgálati személyek öt lehetőség közül választhatták ki, hogyan cselekednének az adott helyzetben, valamint megítélték a szituáció méltányossági viszonyait és a történetben szereplő partner viselkedési stratégiáját. A vizsgálati személyek társas értékorientációját a Van Lange és munkatársai (1997) által szerkesztett kérdőív segítségével mértük fel.

Eredményeink alátámasztották két előzetes hipotézisünket, miszerint minél méltányosabbnak észleli egy személy a saját érdekeit egy szituációban, illetve minél inkább versengőnek észleli a partner viselkedését az adott helyzetben, annál hajlamosabb versengő viselkedési szándék kialakítására. Harmadik hipotézisünket, mely szerint a versengő vagy individualista (proself) társas értékorientációval rendelkező egyének helyzettöl függetlenül hajlamosabbak a versengő viselkedési szándék kialakítására, mint a proszociálisok, nem sikerült igazolnunk. $\mathrm{Az}$, hogy a helyzetre jellemző tényezők észleleteinek átlagai nem voltak szélsőségesek, igazolta hogy a kapcsolat hiánya nem abból fakadt, hogy ezen tényezők (méltányosság és partneri stratégia) túlságosan erősen meghatározták volna a helyzetben kívánatos viselkedésformát. Jelen vizsgálatban nem álltak rendelkezésre olyan további adatok, melyekkel biztonsággal magyarázatot adhattunk volna a kapcsolat hiányára. Ugyanakkor feltételezhető, hogy a korábbi kutatások kísérleti játszmákat alkalmazó módszertanától eltérő, életszerü helyzetleírásokat alkalmazó vizsgálati konstrukció szerepet játszhatott abban, hogy az ugyancsak a kísérleti játszmákhoz hasonlatos eszközzel mért társas értékorientáció nem mutatott kapcsolatot a vizsgálati személyek viselkedési szándékával.

Mivel feltételeztük, hogy ennek ellenére léteznek olyan individuális tényezők, melyek alapján az emberek eltérnek egymástól abban, hogy hogyan észlelik az érdekkonfliktusos helyzetek sajátosságait, illetve hogy ezekben a helyzetekben milyen viselkedési szándék fogalmazódik meg bennük, mintánkban hierarchikus klaszteranalízis segítségével igyekeztünk alcsoportokat találni. A méltányossági viszonyok és a partneri stratégia észlelete, valamint a viselkedési szándék négy szituáció-típusban megjelenő változói alapján három, szignifikáns különbségeket mutató csoportot sikerült azonosítanunk. A csoportok egymástól a méltányossági viszonyok észleletében, valamint viselkedési szándékaikban különböztek jelentősen. Az első csoport „barátságosan” észlelte a helyzetek méltányossági viszonyait, a másik kettőhöz képest minden szituációban méltányosabbnak érezte a partner érdekeit. Viselkedési szándékát is a barátságosság jellemezte: a másik két csoportnál átlagosan alárendelődőbb válaszokat adott a négy szituációban, és szándékát csak minimális mértékben változtatta helyzetröl-helyzetre. A harmadik 
csoport mindkét csoportnál „egocentrikusabb” módon észlelte a helyzetek méltányossági viszonyait, a másik kettöhöz képest minden szituációban méltányosabbnak érezte a saját érdekeit. Mindkét csoportnál átlagosan versengöbb viselkedési szándékot mutatott, melyet elsősorban a partner stratégiájához, másodsorban pedig a méltányossági viszonyokhoz igazított: versengőbb partnerrel szemben és olyankor, amikor a saját érdekeit méltányosabbnak észlelte, még versengőbb viselkedési szándékot fogalmazott meg. A második csoport az előző kettőtől eltérő módon, tendencia-szerủ torzításoktól mentesen észlelte a helyzet méltányossági viszonyait: erösen elkülönültek észleleteiben azok a helyzetek, melyekben a saját érdekeik voltak méltányosabbak azoktól, melyekben a partner érdekei voltak jogosabbnak beállítva. Viselkedési szándékaiban hasonló változatosságot mutatott a csoport: elsősorban a méltányossági viszonyokhoz, másodsorban a partner stratégiájához igazította szándékait, mely a négy szituáción keresztül az erősen versengőtől az erősen alárendelődőig terjedt. A viselkedési szándék méltányossággal és a partner stratégiájával való kapcsolatának iránya az elvárásoknak megfelelően a harmadik csoportnál leírtak szerinti volt.

Eredményeink alapján feltételezzük, hogy az egyének egymás közti különbözőségei nemcsak egy adott helyzetben megfogalmazott viselkedési szándékukban vagy aktuális viselkedésükben foghatók meg, hanem sokkal inkább abban, hogy az egymástól eltérő sajátosságokkal jellemezhető helyzeteket miképpen észlelik, és milyen módon és mértékben igazítják viselkedésüket ezekhez az észleletekhez. A De Dreu, Weingart és Kwon (2000) által felvetett, a tárgyalási helyzetekre vonatkozó motiváció-vezérelt információfeldolgozás elmélete alapján ugyanakkor felmerül az a kérdés is, hogy vajon az észleletekben megjelenő különbözőség nem a már korábban - akár tudattalanul - kialakult viselkedési szándékot tükrözi-e, racionális magyarázatot adva az egyénnek későbbi viselkedésének megválasztására. További kutatásainkkal ezekre a kérdésekre kívánunk kielégítő válaszokat találni.

\section{Irodalom}

Axelrod, R. (1984): The evolution of cooperation. New York, Basic Books.

Bixenstine, V.E., Wilson, K.V. (1969): Effects of level of cooperative choice by other player on choices in prisoner's dilemma game. Part II. Journal of Abnormal and Social Psychology, 67(2), 139-147.

Boone, C., Declerck, C., Suetens, S. (2008): Subtle social cues, explicit incentives and cooperation in social dilemmas. Evolution and Human Behavior, 29(3), 179188.

De Dreu, C.K.W., Boles, T.L. (1998): Share and Share Alike or Winner Take All?: The Influence of Social Value Orientation upon Choice and Recall of Negotiation Heuristics. Organizational Behavior and Human Decision Processes, 76(3), 253276.

De Dreu, C.K.W., Weingart, L.R., Kwon, S. (2000): Influence of social motives on integrative negotiation: A meta-analytic review and test of two theories. Journal of Personality and Social Psychology, 78(5), 889-905.

Deutsch, M. (1949): A theory of cooperation and competition. Human Relations, 2(2), 129-152. 
Deutsch, M. (1984): A jutalom különböző rendszerek szerint történő igazságos elosztásának hatásai. Pszichológia, 4(4), 513-524.

Eek, D., Gärling, T. (2008): A New Look at the Theory of Social Value Orientations: Prosocials Neither Maximize Joint Outcome nor Minimize Outcome Differences but Prefer Equal Outcomes. In: Biel, A., Eek, D., Gärling, T., Gustafsson, M.(Eds.): New issues and paradigms in research on social dilemmas. New York, Springer Verlag. 43-56.

Fiske, S.T. (2006): Társas alapmotívumok. Budapest, Osiris Kiadó.

Fülöp Márta (1995): A versengésre vonatkozó tudományos nézetek. Pszichológia, 4(15), 435-474.

Fülöp Márta (2008): Paradigmaváltás a versengéskutatásban. Pszichológia, 28/2, 113-140.

Gilbert, D.T., Fiske, S.T., Lindzey, G. (Eds.) (1998): Handbook of Social Psychology. Vol.2. New York, McGraw-Hill.

Grzelak, J. (1995): Konfliktus és kooperáció. In: Hewstone, M., Stroebe, W., Codol, J. P., Stephenson, G.M. (szerk.): Szociálpszichológia. Budapest, KJK., 313-339.

Horváth Andrea (2000): A kétszemélyes konfliktusokat befolyásoló tényezők áttekintése. Pszichológia, 20(2), 181-212.

Kelley, H.H., Holmes, J.G., Kerr, N., Reis, H.T., Rusbult, C.E., Van Lange, P.A.M. (2003): An atlas of interpersonal situations. Cambridge, Cambridge University Press.

Kelley, H.H., Stahelski, A.J. (1970): Social interaction basis of cooperators' beliefs about others. Journal of Personality and Social Psychology, 16(1), 66-91.

Kerr, N.L. (1989): Illusions of efficacy: The effects of group size on perceived efficacy in social dilemmas. Journal of Experimental Social Psychology, 25(4), 287-313.

Kramer, R.M., Tyler, T.R. (1995): Trust in organizations. Thousand Oaks, CA., Sage Publications.

Kuhlman, D.M., Marshello, A. (1975): Individual differences in game motivation as moderators of programmed strategic effects in prisoner's dilemma. Journal of Personality and Social Psychology, 32(5), 922-931.

Liebrand, W.B.G., Messick, D.M., Wilke, H.A.M. (1992): Social dielmmas: Theoretical issues and research findings. New York, Pergamon Presss. Elmsford.

Liebrand, W.B.G., Van Run, G. (1985): The effects of social motives on behaviour in social dilemmas in two cultures. Journal of Experimental Social Psychology, 21(1), 86-102.

Maki, J.E., McClintock, C.G. (1983): The accuracy of social value prediction: Actor and observer influences. Journal of Personality and Social Psychology, 45(4), 829-838.

McClintock, C.G., Liebrand, W.B.G (1988): The role of interdependence structure, individual value orientation and other's strategy in social decision making. A transformational analysis. Journal of Personality and Social Psychology, 55(3), 396-409.

Messick, D.M., McClintock, C. (1968): Motivational bases of choice in experimental games. Journal of Experimental Psychology, 4(1), 1-25. 
Oskamp, S. (1971): Effects of programmed strategies on cooperation in the prisoner's dilemma and other mixed-motive games. Journal of Conflict Resolution, 15(2), 225-259.

Pietroni, D., Van Kleef, G.A., De Dreu, C.K.W., Pagliaro, S. (2008): Emotions as strategic information: Effects of other's emotional expressions on fixed-pie perception, demands, and integrative behavior in negotiations. Journal of Experimental Psychology, 44(6), 1444-1454.

Pillutla, M.M., Chen, Xiao-Ping (1999): Social Norms and Cooperation in Social Dilemmas: The Effects of Context and Feedback. Organizational Behavior and Human Decision Processes, 78(2), 81-103.

Rapoport, A. (1976): Experimental games and their uses in psychology. Morristown, NJ., General Learning Press.

Roch, S.G., Samuelson, C.D. (1997): Effects of Environmental Uncertainty and Social Value Orientation in Resource Dilemmas. Organizational Behavior and Human Decision Processes, 70(3), 221-235.

Rusbult, C.E., Van Lange, P.A.M. (1996): Interdependence processes. In: Higgins, E.T., Kruglanski, A.W. (Eds.): Social psychology: Handbook of basic principles. New York, Guilford Press. 546-596.

Smith, E.R., Mackie, D.M. (2001): Szociálpszichológia. Osiris Kiadó. Budapest.

Van Beest, I., Van Kleef, G.A., Van Dijk, E. (2008): Get angry, get out: The interpersonal effects of anger communication in multiparty negotiation. Journal of Experimental Psychology, 44(4), 993-1002.

Van Lange, P.A.M, Bekkers, R., Schuyt, T.N.M., Van Vugt, M. (2007a): From Games to Giving: Social Value Orientation Predicts Donations to Noble Causes. Basic and Applied Social Psychology, 29(4), 375 - 384.

Van Lange, P.A.M, Visser, K. (1999): Locomotion in Social Dilemmas: How People Adapt to Cooperative, Tit-for-Tat, and Noncooperative Partners. Journal of Personality and Social Psychology, 77(4), 762-773.

Van Lange, P.A.M., De Cremer, D., Van Dijk, E., Van Vugt, M. (2007b): Self-interest and beyond. Basic principles of social interaction. In: Higgins, E.T., Kruglanski, A.W. (Eds.): Social psychology: Handbook of basic principles. New York, Guilford Press. 540-561.

Van Lange, P.A.M., De Dreu, C.K.W. (2007): Társas interakció: együttmüködés és versengés. In: Hewstone, M., Stroebe, W. (szerk.): Szociálpszichológia. Budapest, Akadémiai Kiadó.

Van Lange, P.A.M., Otten, W., De Bruin, E.M.N., Joireman, J.A. (1997): Development of prosocial, individualistic, and competitive orientations: Theory and preliminary evidence. Journal of Personality and Social Psychology, 73(4), 733-746.

Yamagishi, T. (1988): The provision of a sanctioning system in the United States and Japan. Social Psychology Quarterly, 51(3), 264-270. 


\section{1. melléklet - „VS” szituáció}

A következökben egy olyan hétköznapi szituáció leírását olvashatja, ami bárkivel megtörténhet. Kérjük, hogy olvassa el alaposan a leírást, majd rövid gondolkodás után az öt lehetöség közül válassza ki, hogy önmagát ismerve. Ön mit tenne ebben a helyzetben. Ha úgy érzi, hogy egyik válaszlehetöség sem fedi pontosan azt, amit Ön valójában cselekedne, válassza ki azt, amelyik a legközelebb áll ahhoz.

Ön egy frissen diplomázott, dolgozó fiatalember/hölgy. Albérletben lakik egy panelházban. Egyik szomszédja egy fiatalokból álló társaság, akik egy este házibulit tartanak. A buli nagyon hangos, minden hang áthallatszik a vékony falakon. Ön nagyon szeretne aludni már; fáradt és másnap nehéz napja lesz: egy nagyon fontos prezentációt kell megtartania a munkahelyén.

Amikor már nem bírja tovább a hangzavart, átmegy a szomszédba, és megkéri a házigazdát, fejezzék be hamarosan a bulit, vagy legalább halkítsanak a zenén. Elmondja, hogy Önnek rendkívül fontos lenne, hogy ki tudja magát pihenni, mert fáradtan biztos, hogy nem sikerülne színvonalasra a másnapi prezentáció. A szomszéd erre azt válaszolja, hogy elöbb-utóbb biztos befejezik a bulit, de mivel különösen jól érzik magukat, a buli vége biztos nem mostanában lesz. Hosszas vitázás után megegyeznek abban, hogy 11-ig tart a buli, utána csend lesz. A szomszéd ígérete ellenére azonban még 11:30-kor is nagy a hangzavar.

\section{Alaposan belegondolva a fentiekbe, mit gondol, mit tenne Ön ebben a helyzetben?}

1. Átmenne a szomszédba és közölné a házigazdával, hogy ha azonnal nem fejeződik be a buli, Ön kénytelen lesz kihívni a rendöröket.

2. Átmenne a szomszédba, és közölné a házigazdával, hogy 30 percen belül fejezzék be a bulit, különben Ön kénytelen lesz kihívni a rendöröket.

3. Átmenne a szomszédba, felajánlva azt a lehetöséget, hogy ha 45 percen belül befejezik ezt az összejövetelt, a következő három hétben bármikor rendezhetnek bulit, Ön nem fog szólni a hangzavar miatt. Ha viszont erre nem hajlandóak, akkor jelezné, hogy amennyiben a buli nem fejeződik be 45 percen belül, Ön kénytelen lesz kihívni a rendörséget.

4. Átmenne a szomszédba, és újra türelmesen elmondaná a problémáját. Megkérné a szomszédot, hogy amennyiben lehetséges, 2 órán belül (még hajnali fél kettő előtt) fejezzék be a bulizást.

5. Várna tovább, bízva abban, hogy a szomszédnak csak eszébe jut, amit ígért, és hamarosan véget vet a bulinak. 


\section{Kulcsszavak:}

társas értékorientáció; érdekkonfliktus; szituatív tényezők; méltányosság; partner stratégiája; viselkedési szándék; helyzetleírások

\section{Élőfejben szereplő rövid cím:}

Viselkedési szándékot befolyásoló tényezők érdekkonfliktusban

\section{A cikk teljes címének angol fordítása:}

Title:

Factors influencing behavioral intentions in social situations involving conflicting interests - beyond social value orientation

\section{Angol nyelvü kivonat:}

\section{Summary:}

The conception of social value orientation defined by Messick and McClintock (1968) is a keystone of the majority of studies dealing with interdependence situations. According to the theory of Messick and McClintock (1968) people can be typed on the basis of their outcome preference in interdependence situations. Wide range of studies (e.g. Kelley, Stahelski, 1970; Kuhlman, Marshello, 1975; Maki, McClintock, 1983; Roch, Samuelson, 1997; Van Lange, Visser, 1999; Van Lange et al., 2007a) applying the method of experimental games to measure social value orientation, behavior or behavioral intentions as well - found relationship between social value orientation and behavioral preferences manifested in interdependence situations. Other studies (e.g. Bixenstine, Wilson, 1969; Oskamp, 1971; Rapoport, 1976; Kelley, Thibault, 1978, in: Kelley et al., 2003; Axelrod, 1984; Pillutla, Chen, 1999) aimed to examine the effect of situational characteristics on behavioral choices in interdependence situations. In our research we studied the effect of two situational factors - equity of interests and strategy of the partner - and social value orientation as an individual characteristic on behavioral intentions. We hypothesized that people develop more competitive behavioral intentions when they judge their own interests being more justified than the partner's, and when the partner applies competitive strategy. Besides, we assumed that people having competitive or individualistic (proself) social value orientation - irrespectively of the situation - form more competitive behavioral intentions than prosocial people. In the research construction of ours we applied real-life situation descriptions instead of the common method of experimental games. After reading these situation descriptions the subjects had to form their behavioral intentions. Our hypotheses regarding the effect of situational factors (equity and strategy of the partner) gained reinforcement, but we did not succeeded in demonstrating the relationship between social value orientation and 
behavioral intention. However, we proved that the sample of our study can be classified into clusters significantly different in perception of equity relations and partner's strategy, as well as in developing behavioral intentions. After all, we managed to find individual differences regarding people's perception style and strategy making when forming behavioral intentions, but these individual differences can not be connected to social value orientation measured by us.

\section{Keywords:}

social value orientation; conflicting interests; situational factors; equity; strategy of partner; behavioral intention; situational description 